\title{
Genetic diversity and plant growth- promoting activity of the dominant bacteria from canola plants in Western Iran
}

\author{
Azadeh Jamalzadeh ${ }^{1}$, Mostafa Darvishnia ${ }^{{ }^{*},}$ Gholam Khodakaramian², Eydi Bazgir ${ }^{1}$ and Doostmorad Zafari
}

\begin{abstract}
Background: Plant growth-promoting bacteria (PGPB) can be used as a safe and sustainable agricultural measure to increase plant yield. In this study, cultivable rhizospheric, endophytic, and epiphytic bacteria associated with canola were isolated on nutrient agar medium. The SDS-PAGE method was used for grouping the bacterial strains. Bacterial strains with more than $80 \%$ similarity in their protein patterns were placed in the same species and selected as a representative for partial 165 rRNA encoding gene sequence analysis.

Results: It was found that the bacteria used in this study belonged to Pseudomonas, Frigoribacterium, Sphingomonas, Sphingobacterium, Microbacterium, Bacillus, and Rhodococcus genera. Three PGP bioactivities including siderophore production, nitrogen fixation ability, and phosphate solubilization were evaluated for 18 Pseudomonas representative strains. All tested strains were able to produce siderophore, although only 5 strains could fix nitrogen and none was able to solubilize phosphate. Greenhouse experiments showed that 4 bacterial strains (i.e., 8312, 642, 1313W, and 9421) significantly affected canola seed germination and seedling growth. Bacterial strain 8312, which was identified as Pseudomonas sp., showed the highest effect on the growth of the canola plant. These results indicated the potential of strain 8312 to be used as a biofertilizer in canola cultivation.

Conclusions: The results of this research indicated that canola-related bacteria were diverse during the flowering stage. One isolate had a significant effect on all canola plant growth factors in the greenhouse. Hence, it is recommended to investigate this strain further in field infestation experiments.
\end{abstract}

Keywords: SDS-PAGE, 16 S rRNA, Gene sequence, Rapeseed, Bacteria, Growth

\section{Background}

Many efforts have been made to find a safe and secure way to increase agricultural production. In this regard, plant growth-promoting bacteria (PGPB) can be used as a safe and sustainable agricultural measure to increase plant growth and yield. This method is more economical and efficient compared to chemical fertilizers while being environmentally friendly (Pathania et al. 2020). PGP bacteria increase the growth and health of their host plants by different mechanisms. They can colonize both externally or internally in

\footnotetext{
* Correspondence: Darvishnia.m@lu.ac.ir; mdarvishnia44@yahoo.com ${ }^{1}$ Department of Plant Protection, Lorestan University, Khorramabad, Iran Full list of author information is available at the end of the article
}

their host plant tissues (Afzal et al. 2019). Epiphytic bacteria can establish and multiply on plant surfaces. The diversity of these bacteria is controlled by climate changes such as temperature, humidity, radiation, wind speed, and rainfall. The sizes and compositions of these bacteria are affected by the nutrient availability at a given site (Fenella and Joshi 2014). The rhizosphere is the soil volume around the plant root, which is directly impacted by the presence of plant roots. Rhizobacteria inhabit plant roots within the soil. In the rhizosphere, the diversity and behavior of microorganisms differ from those of the bulk soil (Fageria et al. 2002). Endophytic bacteria survive and thrive inside plants. A recently identified list of genes 
showed that these bacteria are likely to be involved in endophytic behavior (Ali et al. 2014). Recent studies have highlighted the ability of endophytes to increase plant growth (Kandel et al. 2017). PGPB was increased the plant growth indirectly by suppression of phytopathogens (Hu et al. 2016) or directly. The most well-known direct mechanisms in this regard are nitrogen fixation, phosphate solubilization, production of siderophore, and phytohormones (El-Akhdar et al. 2020). For several decades, different Pseudomonas species have been considered plant growth-promoting bacteria. Numerous experiments have shown that siderophores produced by Pseudomonas species can boost plant growth. For example, Masalha et al. (2000) showed the important role of microbial siderophores in supplying iron for plants grown. Under sterile conditions, the plant showed very little growth and suffered from severe iron deficiency. Sharma et al. (2003) showed that siderophore-producing Pseudomonas strain GRP33 increased chlorophyll levels in plants grown under iron deficiency compared to un-inoculated plants. Vansuyt et al. (2007) demonstrated that Pseudomonas fluorescent C7 synthesized Fe-pyoverdine complex, which leads to an increase in the iron content inside the plant tissues and improves plant growth. Moreover, siderophores secreted by PGPB strains can protect microbial auxins from degradation and enable them to enhance plant growth (Tirry et al. 2018). Nitrogen, one of the most important and essential elements for plant nutrition and growth, is a signaling molecule. Levels of this ion influence roots development and finally the nitrogen uptake rate (De Silveira et al. 2016). Nitrogen fixation ability is an important feature of PGP bacteria that plays a key role in the bio-fertilization of crops in sustainable and nature-friendly agriculture by providing the main source of nitrogen for the plant (Zaidi et al. 2017). Many factors affect the genetic diversity of plant-associated bacterial populations such as the host plant, plant growth stage, and environmental conditions. The plant plays a key role in determining the diversity of rhizosplane and endo-rhizosphere bacteria (Farina et al. 2012).

Canola (Brassica napus) cultivation is increasing in different parts of Iran. Canola production is a highly valued strategy for agricultural policy-makers in Iran to decrease imports of vegetable oils (Zarafshani et al. 2017).

In this research, predominant cultivable bacteria associated with canola were isolated from different canola production fields in western Iran. Their diversity was estimated, some of the PGP properties of the selected isolates were investigated, and one of them was introduced as a bio-fertilizer.

\section{Methods}

\section{Sampling and sample preparation}

The samples were randomly collected between January 2015 and April 2016 from different canola fields (Hyola cultivar) of 5 provinces under the supervision of the agricultural organization in western Iran (Khuzestan, Ilam, Lorestan, Ardabil, and Hamedan). All samples (120 healthy plants with adhering soil that were at the flowering stage) were placed in paper bags, transported to the laboratory, and used for isolation. Five samples from each region were randomly grouped to obtain a representative composite sample. To extract epiphytic bacteria, composed samples (i.e., stems, leaves, and flowers) were separated and their dust was cleaned with cotton. Next, they were placed in 100-ml sterilized distilled water and kept on a 120-rpm shaker for $1 \mathrm{~h}$. A loopful of the resulting suspension was plated on nutrient agar medium and was supplemented with sucrose $\left(5 \mathrm{~g} \mathrm{l}^{-1}\right)$ (EPPO 2011). To isolate endophytic bacteria, plant parts (roots, stems, leaves, and flowers) were surface sterilized and washed in running tap water, followed by washing with sodium hypochlorite solution ( 0.3 to $2 \%$, v/v) for 1 to $3 \mathrm{~min}$ and 3 serial rinses in sterilized distilled water. Plant parts were sliced in $100 \mathrm{ml}$ sterilized distilled water. The suspensions were placed on a 120-rpm shaker for $1 \mathrm{~h}$ to release bacteria from the plant tissues. A loopful of the resulting suspension was streaked on Petri plates containing the above-mentioned medium. To extract rhizosphere microorganisms, roots with adhering soil (rhizospheric soil) were placed in $100 \mathrm{ml}$ sterile distilled water and placed on a 200-rpm shaker at $25^{\circ} \mathrm{C}$ for $1 \mathrm{~h}$. This solution was serially diluted, of which 0.1 to $1 \mathrm{ml}$ was spread on a selective nutrient agar medium (Hammami et al. 2013). Petri dishes were incubated at $25-28{ }^{\circ} \mathrm{C}$ for several days to allow the bacterial growth. Different colony types in terms of shape, size, texture, pigmentation, margin, and elevation picked up were subcultured on fresh Petri plates. The purified colonies were individually stored at $-20{ }^{\circ} \mathrm{C}$ in $30 \%$ glycerol.

\section{Protein extraction and SDS-PAGE}

To extract protein of Gram-negative bacteria, bacterial strains grown on nutrient agar containing $0.5 \mathrm{~g} \mathrm{l}^{-1} \mathrm{NaCl}$ for $24 \mathrm{~h}$ at $25-28{ }^{\circ} \mathrm{C}$ were suspended in $1 \mathrm{ml}$ sample buffer $(0.062 \mathrm{M}$ Tris- $\mathrm{HCl} \mathrm{pH}$ 6.8, 15\% glycerol, $7.5 \%$ mercaptoethanol, $0.6 \% \mathrm{SDS}$ ) and then, they were placed in boiling water for $10 \mathrm{~min}$. After centrifugation at 10, $000 \mathrm{rpm}$ for $10 \mathrm{~min}, 300 \mu \mathrm{l}$ batches of supernatant containing soluble proteins were loaded into each well of the gel (Laemmli 1970). To extract the proteins of Gram-positive bacteria, bacterial isolates grown on nutrient agar were suspended in $1 \mathrm{ml}$ of distilled water. Next, $50 \mu \mathrm{l}$ of $1 \mathrm{M}$ Tris- $\mathrm{HCl} \mathrm{pH} 8.2$ and then, $100 \mu \mathrm{l}$ of 
lysozyme solution (10 $\mathrm{mg}$ of lysozyme per $\mathrm{ml}$ of $0.05 \mathrm{M}$ Tris- $\mathrm{HCl}$ buffer containing $0.02 \mathrm{M}$ EDTA pH 8.2) were added to the vial and were thawed and frozen in triplicate. Subsequently, SDS was added to a final concentration of $2 \%$ and vials were placed in water at $60{ }^{\circ} \mathrm{C}$ for 10 to $15 \mathrm{~min}$. After centrifugation at 12,000 rpm for $2 \mathrm{~min}$, $300 \mu \mathrm{l}$ batches of supernatant were transferred to new vials and loaded into each well of the gels (Chaasy and Giuffrida 1980). Electrophoresis was performed according to a modified Laemmli method in a constant current of $20 \mathrm{~mA}$ for $7 \mathrm{~h}$ using 5\% stacking gel (pH 6.8) and a $12 \%$ running gel $(\mathrm{pH} 8.8)$. After electrophoresis, Coomassie brilliant blue solution was added to the mix for gel staining using $45 \% \mathrm{v} / \mathrm{v}$ methanol, $10 \% \mathrm{v} / \mathrm{v}$ glacial acetic acid, and $0.01 \%$ Coomassie brilliant blue R250. Afterward, it was kept for $24 \mathrm{~h}$ at room temperature and then, was destained in the same solution without Coomassie brilliant blue (45\% v/v methanol and $10 \% \mathrm{v} / \mathrm{v}$ glacial acetic acid) until the gel was rehydrated (Laemmli 1970).

\section{DNA extraction}

The DNA extraction was prepared by the alkaline lysis method (Arabi et al. 2006). The suspension of bacterial cells was prepared in $1 \mathrm{ml}$ of sterile distilled water (optical density at $600 \mathrm{~nm}, 1$ ). Then, $30 \mu \mathrm{l}$ of $\mathrm{KOH} 5 \%$ was added to the cells suspension, followed by placing it in boiling water for $10 \mathrm{~min}$. Centrifugation was conducted at $12,000 \mathrm{rpm}$ for $2 \mathrm{~min}$ and $60 \mu \mathrm{l}$ of the supernatant was removed carefully (DNA extract). An appropriate amount of DNA of genomic was determined and used in PCR reactions.

\section{PCR amplification of the 16S rRNA gene and analysis}

Two conserved primers fD1 (5-AGA GTT TGA TCC TGG CTC AG-3) and rP2 (5-ACG GCT ACC TTG TTA CGA CTT-3) were used to amplify the almost complete 16S rRNA gene sequence (1506 bp). The polymerase chain reaction (PCR) was performed using a PCR thermocycler (Techno-TC-512; UK). About $25 \mu \mathrm{l}$ of reaction volume contained $1 \mu \mathrm{l}$ of bacterial DNA as a template for PCR procedures, $0.1 \mathrm{mM}$ of primers, $1 \mathrm{mM}$ $\mathrm{MgCl} 2,20 \mathrm{mM}$ of each dNTP, and $0.5 \mathrm{U}$ Taq DNA polymerase (Cinna Gen, Iran). The thermal cycling used for this reaction was as follows: initial denaturation at 94 ${ }^{\circ} \mathrm{C}$ for $5 \mathrm{~min}, 94{ }^{\circ} \mathrm{C}$ for $45 \mathrm{~s}$ followed by 30 cycles of 58 ${ }^{\circ} \mathrm{C}$ for $1 \mathrm{~min}, 72{ }^{\circ} \mathrm{C}$ for $90 \mathrm{~min}$, and a final extension at $72{ }^{\circ} \mathrm{C}$ for $10 \mathrm{~min}$. PCR products were sent to a sequencing service (Macrogen, Seoul, South Korea). The nucleotide sequences were aligned in the NCBI database using nucleotide BLAST software (NCBI BLAST ${ }^{\circ}$ homepage). Phylogenetic analysis was performed using MEGA 7.0.26 software and neighbor-joining method with 1000 repetitions bootstrap to confirm the stability of the relationships (Kumar et al. 2016). The nucleotide sequences of $16 \mathrm{~S}$ rRNA gene segments from different bacterial samples determined in this research have been deposited in the GenBank database under accession numbers (MW703484 and MW712709 to MW712715).

\section{In vitro screening for antagonism (dual test)}

The antagonistic effects of all 362 isolates were evaluated against the causative agent of rapeseed blackleg disease (Leptosphaeria maculans) using the dual-culture method and the inhibition percentage was calculated using the following formula (Vincent 1947):

\%Inhibition of mycelial growth $=[(C-D) / C)] \times 100$

Where $C$ is mycelial growth of pathogen in absence of antagonists and $D$ is mycelial growth of pathogen in presence of antagonists. The experiments were conducted in a completely randomized design with three replicates.

\section{Evaluation of plant growth-promotion properties}

Regarding the ability of some Pseudomonas isolates (18 strains) to biologically control the blackleg disease, these isolates (13 leaf epiphytes, 1 stem epiphyte, 1 flower epiphyte, 1 root endophyte, and 2 leaf endophyte) were selected for the next laboratory experiments (plant growth-promotion properties and greenhouse assays). Siderophore production (Schwyn and Neilands 1987), phosphate solubilization (Lynn et al. 2013), and nitrogen fixation (Döbereiner 1998) activities were performed for the selected isolates.

\section{Effect of bacterial seed priming on germination and growth in greenhouse}

For greenhouse assays, seeds of B. napus (cv. Hyola) obtained from Agriculture and Natural Resources Research and Education Center of Hamedan were surface sterilized by $1 \%$ sodium hypochlorite for $1 \mathrm{~min}$ and then were washed in triplicate in sterile distilled water (Nezaret and Gholami 2009). Canola seeds were then inoculated with each bacterial suspension to a final concentration of $10^{6} \mathrm{cfu} \mathrm{m}^{-1}$ containing $1 \%$ Carboxymethylcellulose in $170 \mathrm{rpm}$ for $12 \mathrm{~h}$ at $28{ }^{\circ} \mathrm{C}$. In the control treatment, seeds were inoculated with distilled water. The treated seeds were exposed to sterile air for about $6 \mathrm{~h}$ to dry completely (Kumar et al. 2011) and then were sown in pots with 10 seeds per pot. The soil used for the experiment was made by combining sand and compost (1:1 $\mathrm{v} /$ v) and was sterilized by autoclaving. Seedlings were grown in a greenhouse with $12 \mathrm{~h}$ of light at $25{ }^{\circ} \mathrm{C}$ and were irrigated with distilled water. Thirty days after sprouting, plants were harvested and vegetative 
parameters were measured according to OrozcoMosqueda et al. (2013) as follows:

$$
\begin{aligned}
& V I=G R \times L \\
& G R=(S G / N S) \times 100 G R=\frac{S G}{N S} \times 100
\end{aligned}
$$

Where $V I$ is Vigour index, GR is Germination rate (\%), $\mathrm{L}$ is the total plant length, $S G$ is the number of seeds germinated from total number of seeds, and $N S$ is the total number of seeds.

A completely randomized block design with three replicates was used to perform this experiment. The data were analyzed using SAS9 software and the mean data were compared using Duncan's multiple range tests at 5\% level $(P \leq 0.05)$.

\section{Results}

Isolation, screening, identification, and diversity of bacteria

A total of 362 bacterial isolates associated with canola plants based on their growth on nutrient agar medium was obtained. Of these 362 isolates, 160 were from roots (94 rhizobacteria and 66 endophytes), 74 from stems (90 epiphytes and 32 endophytes), 98 from leaves (12 epiphytes and 42 endophytes), and 30 from flowers (22 epiphytes and 4 endophytes). These isolates represented $25.9,18.2,20.4,27$, and $8.2 \%$ of the bacteria, respectively. Samples were collected at the flowering stage.
In this study, SDS-PAGE was used to screen the isolates and to prove that this method is of high efficiency to screen and group the isolates. Isolates with more than $80 \%$ similarity in their protein patterns were placed in the same species (Fig. 1). From each group of protein electrophoresis patterns obtained, a representative bacterium belonging to the same cluster was selected for the partial 16S rRNA gene sequence analysis. The partial sequencing of the $16 \mathrm{~S}$ rRNA gene of representative strains showed that isolates belonged to the Pseudomonas, Frigoribacterium, Sphingomonas, Sphingobacterium, Microbacterium, Bacillus, and Rhodococcus genera (Fig. 2).

\section{In vitro antagonism of Leptosphaeria maculans}

According to the results of dual-cultures tests of bacterial isolates against Leptosphere maculans, 18 Pseudomonas isolates exhibited significant antagonistic activity against Leptosphaeria maculans.

\section{PGP traits of bacterial isolates}

All the 18 selected Pseudomonas isolates were evaluated for plant growth-promoting characteristics viz siderophore production, nitrogen fixation, and phosphate solubilization. The isolates were able to produce siderophore, which appeared by an orange halo formation around the bacterial culture site (Fig. 3). Five isolates could fix nitrogen (Fig. 4). In this research, the selected isolates were unable to solubilize phosphate. Overall, the

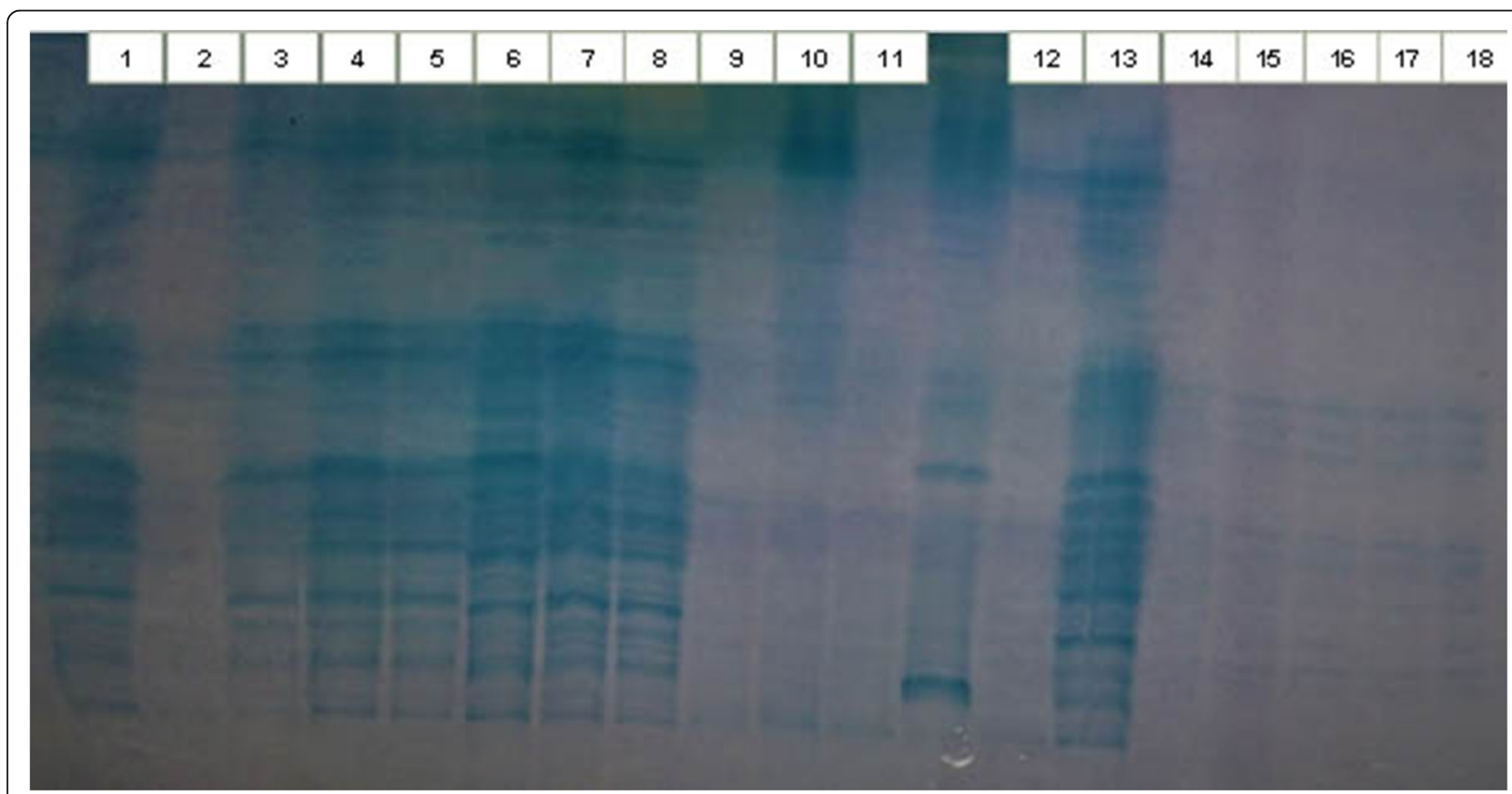

Fig. 1 Protein pattern of selected Pseudomonas isolates. 1: 4532, 2: 122,3: 642,4: 42,5: 4531,6: LN1112,7: 9421,8: S1121W,9: 8312,10: 1111,11: 12122,12: 1RN2,13: 12112,14: F7122,15: LN1111,16: 8311,17: 943,18: .1313W 


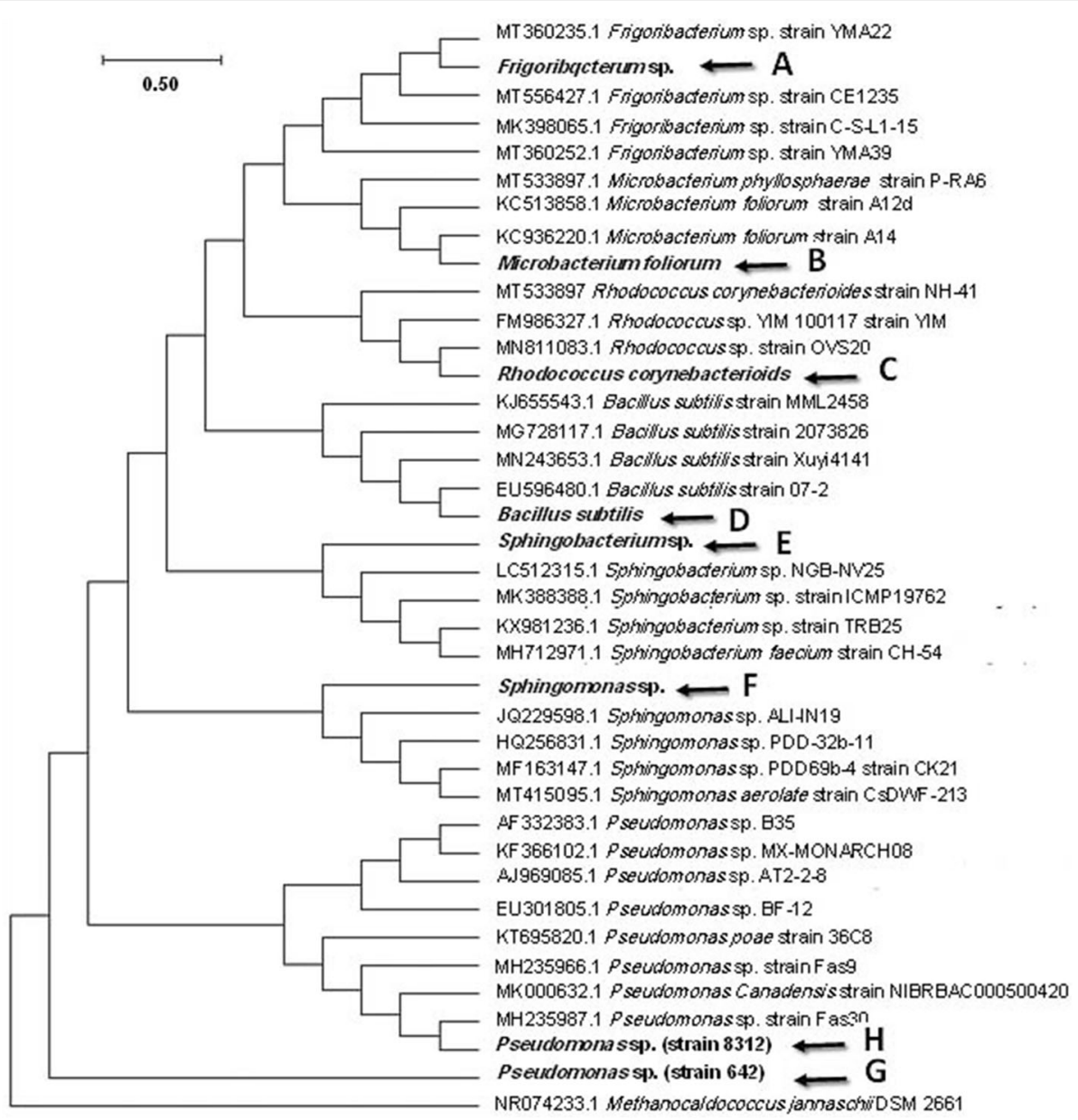

Fig. 2 Phylogenetic analysis based on 165 rRNA gene sequence of representative bacterial strains isolated from canola plants (A, B, C, D, E, F, and G) and H: isolate 8312. Methanocaldococcus jannaschii DSM 2661 (NR074233.1) has been used as an outgroup

isolates represented some properties associated with plant growth promotion.

\section{In vivo seed priming effect on seed germination and plant growth factors}

The ability of 18 pseudomonas isolates to increase seed germination and growth of canola plants was investigated by the priming method (Figs. 5 and 6). The test results showed that bacteria had a positive effect on seed germination and plant growth. Strains 8312 and 642 significantly increased root length than the control and the other treatments did not show significant difference than the control. Treatments 8312, 642, 1313W, and 9421 had the maximum wet weights compared to the control. The greatest effect on germination was related to 8312 and $1313 \mathrm{~W}$ treatments. Treatment 8312 showed a significant difference with the control, in other factors. Treatment 8312 indicated a significant difference in all factors compared to the control, and it was recognized as the best effective isolate on canola seed growth factors. These isolates were leaf epiphyte bacteria.

\section{Discussion}

In this research, PGP bacteria associated with canola ( $B$. napus) isolated on nutrient agar medium were supplemented with sucrose for investigating genetic diversity and the presence of plant growth-promoting bacteria. There is a little information about bacteria associated with canola in western Iran. In this study, the flowering stage was selected to isolate all canola-related bacteria because the plant has the highest level of physiological activity during the flowering stage (Idris et al. 2004). Houlden et al. (2008) reported an increase in the population of Pseudomonas in the flowering stage of pea. However, Farina et al. (2012) showed that canola root-related bacteria in the rosette stage were more diverse than at the time of flowering.

SDS-PAGE method is a very useful method to prove to be extremely reliable for the identification of bacteria 


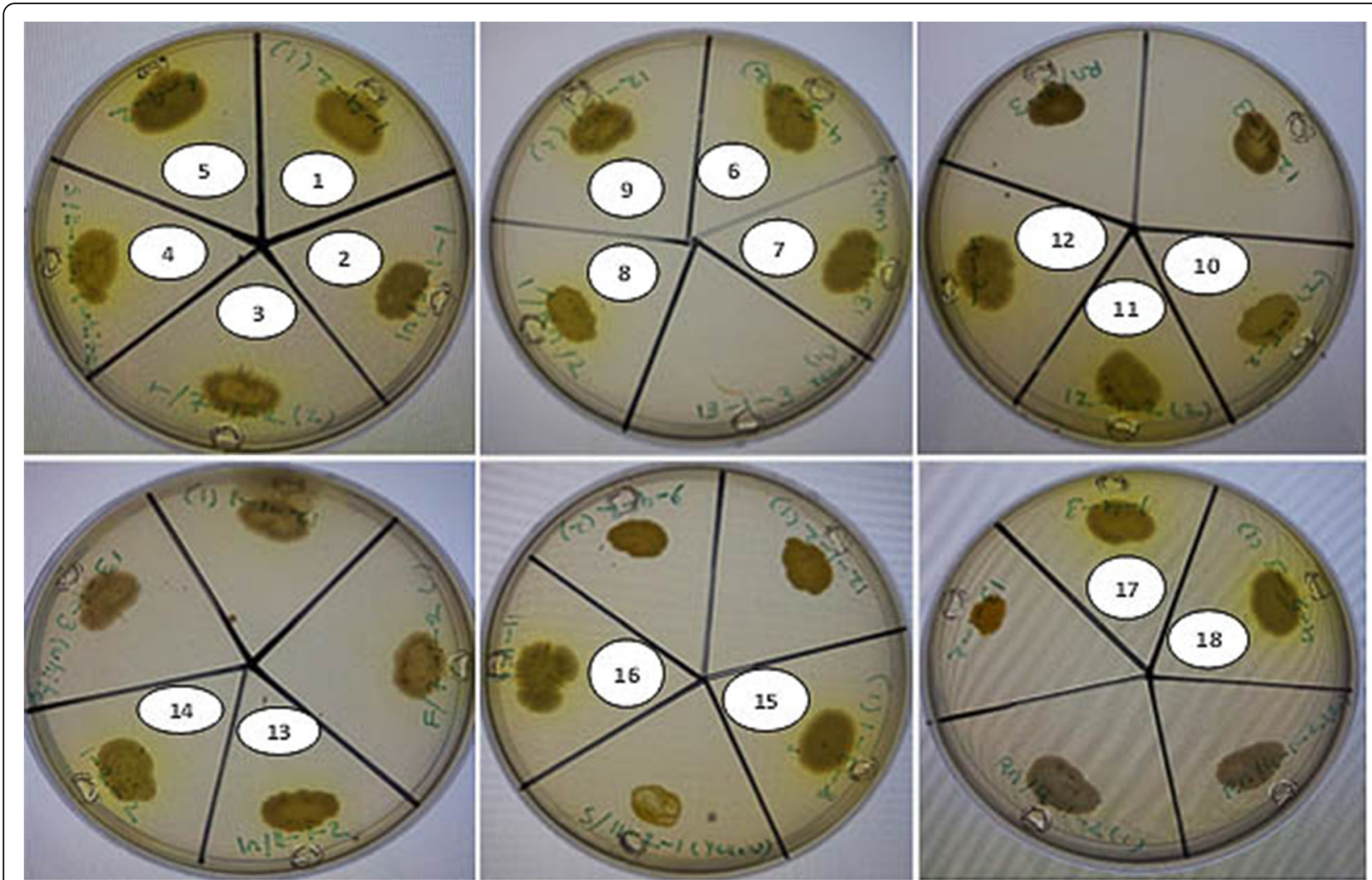

Fig. 3 Ability of the selected Pseudomonas isolates to produce siderophore. 1:9421, 2: LN1111, 3: F7122, 4: S1121W, 5: 642, 6: 4532, 7: 1313W, 8: 1RN2, 9: 12112, 10: 8312, 11: 12122, 12: 42, 13: LN1112, 14: 122, 15: 8311, 16: 1111, 17: 943, 18: 4531

on the species level. Also, the technique allowed estimating molecular mass (Thierry et al. 2002). Strains belonging to a single species have qualitatively highly similar protein patterns. Visual inspection of the protein patterns was sufficient to distinguish among different species (Esteban et al. 2003). SDS-PAGE was a fast method to compare large numbers of strains to screen them.

Based on 16S rRNA sequences, isolated bacteria belonged to the Pseudomonas, Frigoribacterium, Sphingomonas, Sphingobacterium, Microbacterium, Bacillus, and Rhodococcus genera. Similar to obtained results, bacteria belonging to the genus Pseudomonas were one of the most abundant genera isolated from canola in some other studies. In the study conducted by Siciliano and Germida (1999), a large number of Pseudomonas was isolated from rapeseed. Bertrand et al. (2001) identified the Xanthomonas, Escherichia, Burkholderia, Azospirillum, Agrobacterium, Rhizobium, and Pseudomonas genera from the endorhizosphere and rhizoplane of canola plants. Misko and Germida (2002) reported that Pseudomonas was one of the most abundant genus (35\%) in bacterial populations isolated from rapeseed. Also, Stenotrophomonas, Flavobacterium, and Arthrobacter had a high abundance. Farina et al. (2012) reported that bacteria belonging to the Agrobacterium, Burkholderia, Enterobacter, and Pseudomonas genera

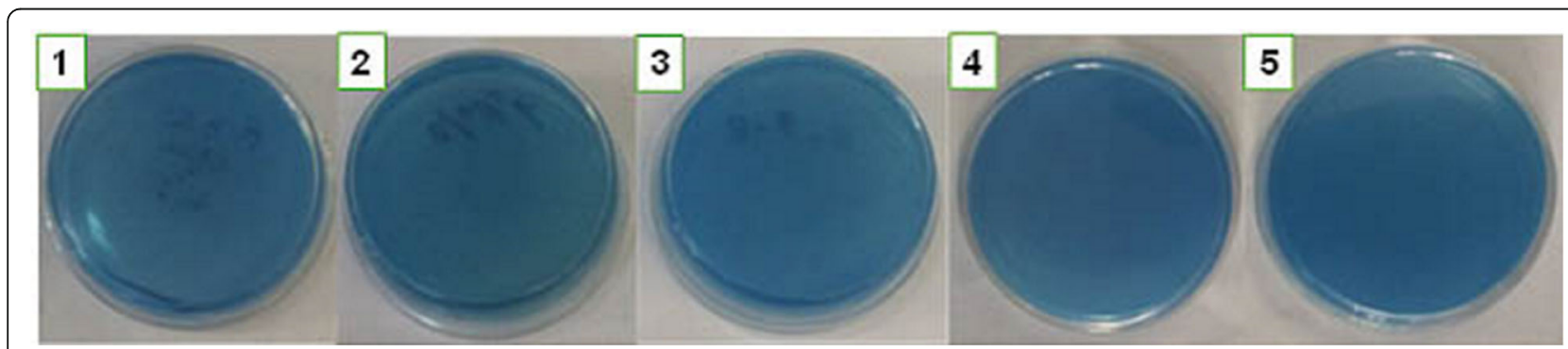

Fig. 4 Nitrogen fixation capacity of the selected Pseudomonas isolates. 1: 8312, 2: 642, 3: 4532, 4: 1111, 5: 1RN2 


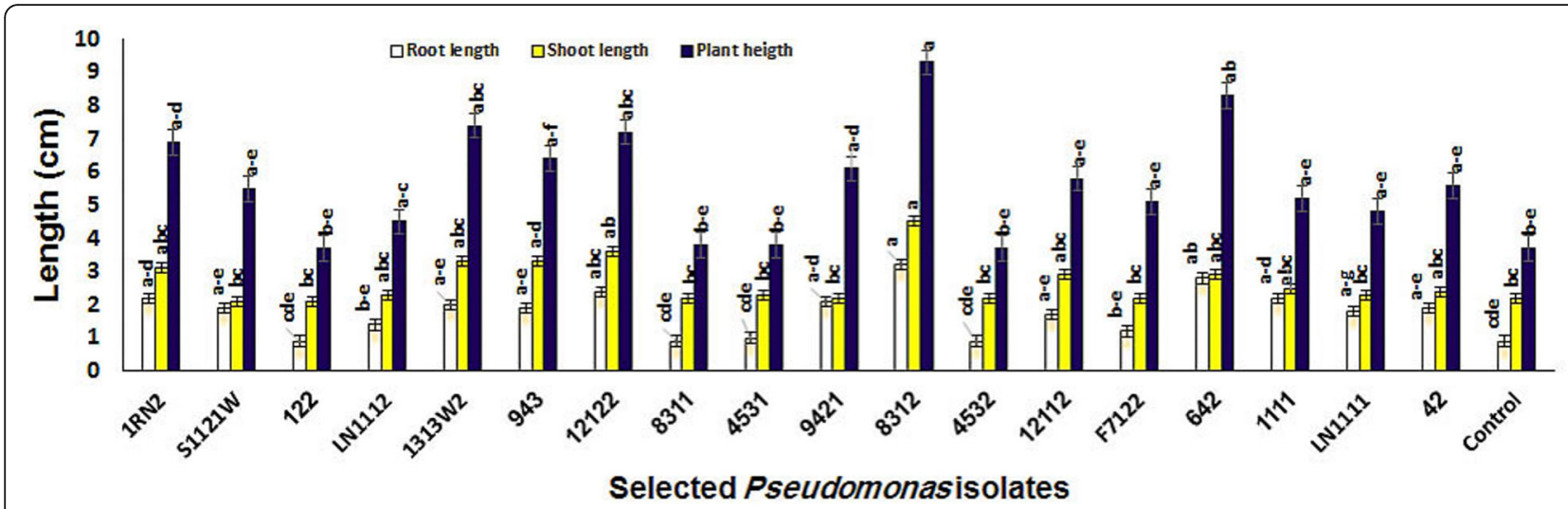

Fig. 5 Effect of canola seed priming by selected Pseudomonas isolates on root, shoot and plant length of canola in greenhouse conditions. Each treatment had three replications and treatments with common letters in Duncan test at 5\% level were not significantly different from each other

had the highest abundance among all bacteria isolated from the rhizosphere and roots, as well as the isolated strains belonging to the Sphingomonas in roots of canola at the flowering stage. In the present research, Sphingomonas was identified in all samples in the flowering stage. Besides, Gram-positive Bacillus and Microbacterium bacteria were isolated and identified from canola plants that had been isolated from canola plants several times before (Card et al. 2015).

Plant growth-promoting bacteria use different methods to increase plant growth and yield. The role of these bacteria in plant nutrition is one of the direct mechanisms used to promote plant growth and development. They can facilitate the uptake of plant nutrients or provide plant growth-promoting nutrition elements that synthesize by the bacterium (Pandya et al. 2015). A bacterium may use one or more mechanisms during the time of plant growth. In this study, 3 plant growthpromoting characteristics (i.e., siderophore production, nitrogen fixation, and phosphate solubilization) were tested on selected isolates.
In the present study, all the selected isolates were able to produce siderophore on CAS agar plate. Siderophores are low-molecular-mass $(\sim$ 400-1500 Da) compounds that bind to Fe3+ (an available form of iron). This form of iron is produced by microorganisms such as bacteria under iron-limiting conditions to keep it out of the reach of plant pathogens and protect the plant (Beneduzi et al. 2013). This mechanism was reported to play a role in enhancing the growth of seedlings (Rudolph et al. 2015) and increasing their yield by enhancing the absorption of iron by the plants (Saha et al. 2015).

In this study, the nitrogen-fixing ability was reported in the strains $8312,642,1111,4532$, and 1RN2. N-fixing bacteria had a significant effect on the biofertilization of crops (Farina et al. 2012). Ke et al. (2019) stated that nitrogen-fixing bacterium $P$. stutzeri A1501 improved the growth of maize under experimental greenhouse conditions. They suggested that biologically fixed nitrogen transfer is maybe the main reason for maize growth promotion.

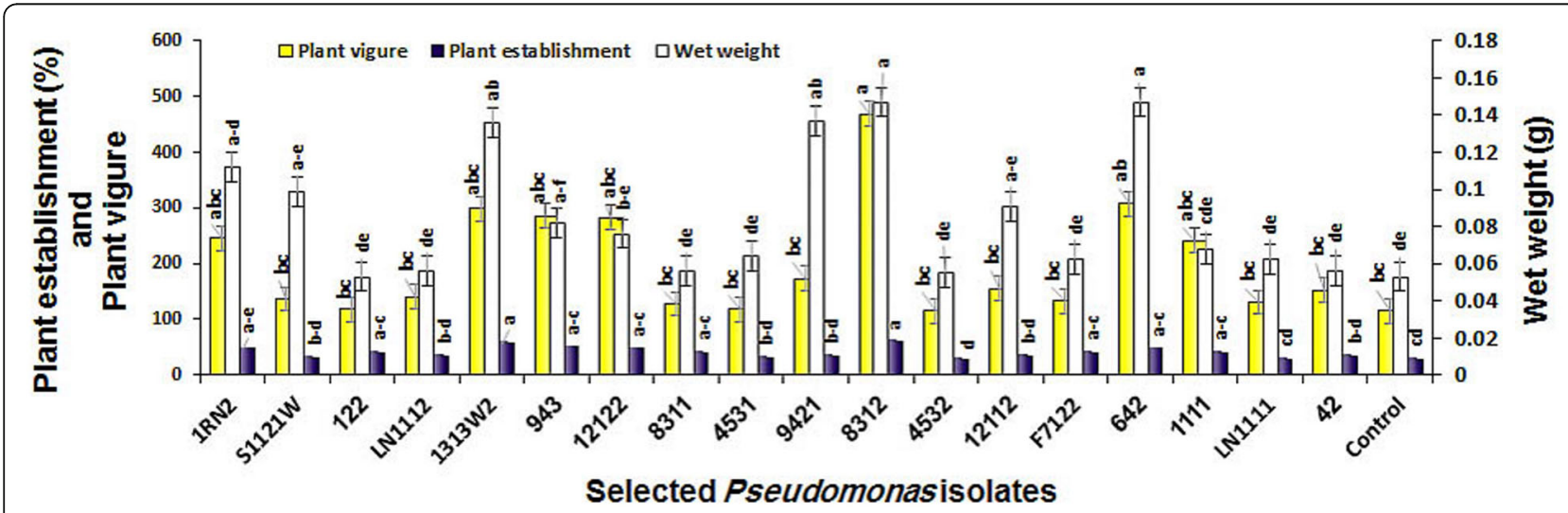

Fig. 6 Effect of canola seed priming by selected Pseudomonas isolates on wet weight, plant establishment and vigor of canola in greenhouse conditions. Each treatment had three replications and treatments with common letters in Duncan test at $5 \%$ level were not significantly different from each other 
In this research, the selected isolates were unable to solubilize phosphate. According to De Freitas et al. (1997) experiments, phosphate-solubilizing rhizobacteria without increasing phosphate uptake significantly increased the growth of canola plant in P-deficient soil amended with rock phosphate in potting soil. Hence, they concluded that P-solubilization was not the main mechanism for enhancing plant growth. Meyer et al. (2019) showed that plant growth and phosphate uptake were significantly reduced in sterilized soil.

Greenhouse observations revealed that inoculation of canola seeds (cv. Hyola) with 4 PGPR isolates (8312, 642, 1313W, and 9421) among 18 bacterial isolates led to a significant increase in germination percentage and growth of rapeseed. Isolates 8312 and 642 had two characteristics related to plant growth enhancement (siderophore production and nitrogen-fixing ability) that were studied in this research. Isolates 1313W and 9421, like other isolates, were only capable of producing siderophore. However, they had a significant impact on some plant growth factors. In comparison, isolates 1111, 4532, and 1RN2, which had 2 characteristics of siderophore production and nitrogen fixation ability, did not have a significant effect on growth factors. Therefore, a PGP bacterial isolate used a specific mechanism or several mechanisms simultaneously to increase plant growth. The presence of several characteristics cannot be a definite reason for the effect on increasing plant growth. Moreover, properties that were effective in increasing plant growth in one isolate may not be effective or be less effective in the other isolates. In this research, 642 and $1313 \mathrm{~W}$ isolates showed a significant increase than the control in 2 factors and strain 8312 in all the studied factors. This probably could be related to other plant growth-promoting traits that were not investigated in this study. Strain 8312, confirmed as Pseudomonas sp. showed the best effect on canola plant growth. This result suggested the potential of this isolate for using as a biofertilizer. Nevertheless, many steps have been taken, for estimating a PGPR-potential to a biofertilizer application to find a suitable formulation for field use.

\section{Conclusions}

The results indicated that canola-related bacteria were diverse during the flowering stage. Pseudomonas, Frigoribacterium, Sphingomonas, Sphingobacterium, Microbacterium, Bacillus, and Rhodococcus genera isolated from all the plant parts were analyzed. Several of them were able to produce siderophore and fix nitrogen. These bacteria had a significant effect on canola plant growth factors in the greenhouse. Isolate 8312 (confirmed as Pseudomonas sp.) had a significant effect on all plant growth factors. Hence, it is recommended to investigate this strain further in field infestation experiments.

\section{Abbreviations}

16SrRNA: 16 subunit ribosomal ribonucleic acid; CAS-Agar: Chrome azurol Sagar; cv: Cultivar; DNA: Deoxynuleotideacid; NCBI: National Center for Biotechnology Information; NJ: Neighbor-joining; OD: Optical density; PCR: Polymerase chain reaction; PGPB: Plant growth-promotion bacteria; Psolubilizing: Phosphate solubilizing; SDS: Sodium dodecyl sulfate; SDSPAGE: Sodium dodecyl sulfate-polyacrylamide gel electrophoresis; sp: Species

\section{Acknowledgements}

Not applicable.

\section{Authors' contributions}

JA, DM, KG, ZD, and BE conceptualized the project. JA isolated bacteria, carried out in vitro, biochemical, and greenhouse experiments, data analyses, final interpretation of data, and original manuscript draft preparation. DM and KG was involved in the conceptualization, supervision, final interpretation of data, and editing of the manuscript. All authors have read and approved the manuscript.

\section{Funding}

This research is funded by the Lorestan University under PhD dissertation grant. The Bu-Ali Sina University supported experimental facilities to carry out experiments.

Availability of data and materials

All data are available in the manuscript.

\section{Declarations}

Ethics approval and consent to participate

Not applicable.

Consent for publication

Not applicable.

\section{Competing interests}

The authors declare that they have no competing interests.

\section{Author details}

'Department of Plant Protection, Lorestan University, Khorramabad, Iran.

${ }^{2}$ Department of Plant Protection, Bu-Ali Sina University, Hamedan, Iran.

Received: 19 March 2021 Accepted: 12 June 2021

Published online: 30 June 2021

\section{References}

Afzal I, Shinwari ZK, Sikandar S, Shahzad S (2019) Plant beneficial endophytic bacteria: mechanisms, diversity, host range and genetic determinants. Microbiol Res 221:36-49. https://doi.org/10.1016/j.micres.2019.02.001

Ali S, Duan J, Charles TC, Glick BR (2014) A bioinformatics approach to the determination of genes involved in endophytic behavior in Burkholderia spp. J Theor Biol 343:193-198. https://doi.org/10.1016/j.jtbi.2013.10.007

Arabi F, Nikravesh Z, Babaizad V, Rezaeian V, Rahimian H (2006) Occurrence of bacterial leaf spot and blight of garden beet caused by Pseudomonas syringae pv. aptata in Iran. Iranian J Plant Pathol 42:655-671

Beneduzi A, Moreira F, Costa PB, Vargas LK, Lisboa BB, Favreto R, Baldani Jl, Passaglia LMP (2013) Diversity and plant growth promoting evaluation abilities of bacteria isolated from sugarcane cultivated in the South of Brazil. Appl Soil Ecol 63:94-104. https://doi.org/10.1016/j.apsoil.2012.08.010

Bertrand H, Nalin R, Bally R, Cleyet-Marel JC (2001) Isolation and identification of the most efficient plant growth-promoting bacteria associated with canola (Brassica napus). Biol Fertil Soils 33:152-156. https://doi.org/10.1007/s00374 0000305

Card SD, Hume DE, Roodi D, McGill CR, Millner JP, Johnson RD (2015) Beneficial endophytic microorganisms of Brassica - A review. Biol Control 90:102-112. https://doi.org/10.1016/j.biocontrol.2015.06.001

Chaasy BM, Giuffrida A (1980) Method for the lysis of Gram-positive, asporogenous bacteria with lysozyme. Appl Environ Microbiol 39(1):153-158. https://doi.org/10.1128/AEM.39.1.153-158.1980 
De Freitas JR, Banerjee MR, Germida JJ (1997) Phosphate-solubilizing bacteria enhance the growth and yield but not phosphate uptake of canola (Brassica napus L.). Biol Fertil Soils 24:358-364

De Silveira APD, Sala VMR, Cardoso EJBN, Labanca EG, Cipriano MAP (2016) Nitrogen metabolism and growth of wheat plant under diazotrophic endophytic bacteria inoculation. Appl Soil Ecol 107:313-319. https://doi.org/1 0.1016/j.apsoil.2016.07.005

Döbereiner J (1998) Isolation and identification of aerobic nitrogen-fixing bacteria from soil and plants. In: Alef K, Nannipieri P (eds) Methods in applied soil microbiology and biochemistry. Academic, San Diego, pp 134-141

El-Akhdar I, Elsakhawy T, Abo-Koura HA (2020) Alleviation of salt stress on wheat (Triticum aestivum L.) by plant growth promoting bacteria strains Bacillus halotolerans MSR-H4 and Lelliottia amnigena MSR-M49. J Adv Microbiol 20: 44-58. https://doi.org/10.9734/JAMB/2020/v20i130208

Eppo (2011) Curtobacterium flaccumfaciens pv. flaccumfaciens. Bull OEPP/EPPO 41: 320-328

Esteban J, Molleja A, Cabria F, Soledad Jimenez M (2003) SDS-PAGE for identification of species belonging to the Mycobacterium fortuitum complex. Clin Microbiol Infect 9:327-331. https://doi.org/10.1046/j.1469-0691.2003. 00542.x

Fageria NK, Baligar VC, Clark RB (2002) Micronutrients in crop production. Adv Agron 77:185-268. https://doi.org/10.1016/S0065-2113(02)77015-6

Farina R, Beneduzi A, Ambrosini A, de Campos SB, Lisboa BB, Wendisch V, Vargas LK, Passaglia LMP (2012) Diversity of plant growth-promoting rhizobacteria communities associated with the stages of canola growth. Appl Soil Ecol 55: 44-52. https://doi.org/10.1016/j.apsoil.2011.12.011

Fenella MWN, Joshi SR (2014) Distribution pattern analysis of epiphytic of bacteria on ethnomedicinal plant surfaces: A micrographical and molecular approach. J Microsc Ultrastruct 2(1):34-40. https://doi.org/10.1016/j.jmau.2 014.02 .003

Hammami I, Hsouna AB, Hamdi N, Gdoura R, Triki MA (2013) Isolation and characterization of rhizosphere bacteria for the biocontrol of the dampingoff disease of tomatoes in Tunisia. CR Biol 336(11-12):557-564. https://doi. org/10.1016/j.crvi.2013.10.006

Houlden A, Timms-Wilson TM, Day MJ, Bailey MJ (2008) Influence of plant developmental stage on microbial community structure and activity in the rhizosphere of three field crops. FEMS Microbiol Ecol 65(2):193-201. https:// doi.org/10.1111/j.1574-6941.2008.00535.X

Hu J, Wei Z, Friman VP, Gu SH, Wang XF, Eisenhauer N, Yang TJ, Ma J, Shen Q, Xu YC, Jousset A (2016) Probiotic diversity enhances rhizosphere micribiome function and plant disease suppression. Am Soc Microbiol 7(6):e1790-16. https://doi.org/10.1128/mBio.01790-16

Idris R, Trifonova R, Puschenreiter M, Wenzel WW, Sessitsch A (2004) Bacterial communities associated with flowering plants of the Ni hyperaccumulator Thlaspi goesingense. Appl Environ Microbiol 70(5):2667-2677. https://doi.org/1 0.1128/AEM.70.5.2667-2677.2004

Kandel SL, Firrincieli A, Joubert PM, Okubara PA, Leston ND, McGeorge KM, Mugnozza GS, Harfouche A, Kim SH, Doty SL (2017) An in vitro study of biocontrol and plant growth promotion potential of Salicaceae endophytes. Front Microbiol 8:386. https://doi.org/10.3389/fmicb.2017.00386

Ke X, Feng S, Wang J, Lu W, Zhang W, Chen M, Lin M (2019) Effect of inoculation with nitrogen-fixing bacterium Pseudomonas stutzeri A1501 on maize plant growth and the microbiome indigenous to the rhizosphere. Syst Appl Microbiol 42(2):248-260. https://doi.org/10.1016/j.syapm.2018.10.010

Kumar AP, Shruti A, Kumar VS, Kumar SS, Prashad SK (2011) Characterization of plant growth promoting bacteria from soil of central and upper Himalayan region. Int J Appl Biol Pharmac Thech 2(1):363-369 https://www.researchga te.net/publication/321128143

Kumar S, Stecher G, Tamura K (2016) MEGA7: molecular evolutionary genetics analysis version 7.0 for bigger datasets. Mol Biol Evol 33(7):1870-1874. https://doi.org/10.1093/molbev/msw054

Laemmli UK (1970) Cleavage of structural proteins during the assembly of the head of bacteriophage T4. Nature 227:680-685

Lynn TM, Win HS, Kyaw EP, Latt ZK, Yu SS (2013) Characterization of phosphate solubilizing and potassium decomposing strains and study on their effects on tomato cultivation. Int J Innov Appl Stud 3(4):959-966 https://www.resea rchgate.net/publication/249968379

Masalha J, Kosegarten H, Elmaci O, Mengel K (2000) The central role of microbial activity for iron acquisition in maize and sunflower. Biol Fertil Soils 30:433439. https://doi.org/10.1007/s003740050021
Meyer G, Maurhofer M, Frossard E, Gamper H, Mader P, Meszaros E, SchonholzerMauclaire L, Symanczik S, Oberson A (2019) Pseudomonas protegens CHAO does not increase phosphorus uptake from 33P labeled synthetic hydroxyapatite by wheat grown on calcareous soil. Soil Biol Biochem 131: 217-228. https://doi.org/10.1016/j.soilbio.2019.01.015

Misko AL, Germida JJ (2002) Taxonomic and functional diversity of pseudomonads isolated from the roots of field-grown canola. FEMS Microbiol Ecol 42(3):399-407. https://doi.org/10.1016/S0168-6496(02)00355-0

Nezaret S, Gholami A (2009) Screening plant growth promoting rhizobacteria for improving seed germination, seedling growth and yield of maize. Pak J Biol Sci 12(1):26-32. https://doi.org/10.3923/pjbs.26.32

Orozco-Mosqueda MDC, Velazquez-Becerra C, Macias-Rodriguez LI, Santoyo G, Flores-Cortez I, Alfaro-Cuevas R, Valencia-Cantero E (2013) Arthrobacter agilis UMCV2 induces iron acquisition in Medicago truncatula (strategy I plant) in vitro via dimethylhexadecylamine emission. Plant Soil 362:51-66. https:// doi.org/10.1007/s11104-012-1263-y

Pandya M, Rajput M, Rajkumar S (2015) Exploring plant growth promoting potential of non rhizobial root nodules endophytes of Vigna radiate. J Microbiol 84:80-89. https://doi.org/10.1134/S0026261715010105

Pathania P, Rajta A, Singh PC, Bhatia R (2020) Role of plant growth-promoting bacteria in sustainable agriculture. Biocat Agric Biotech 20(20):S1878-\$8181. https://doi.org/10.1016/j.bcab.2020.101842

Rudolph N, Labuschagne N, Aveling TAS (2015) The effect of plant growth promoting rhizobacteria on seed germination and seedling growth of maize. Seed Sci Technol 43:507-518. https://doi.org/10.15258/sst.2015.43.3.04

Saha M, Sarkar S, Sarkar B, Sharma BK, Bhattacharjee S, Tribedi P (2015) Microbial siderophores and their potential applications: a review. Environ Sci Pollut Res 23(5):3984-3999. https://doi.org/10.1007/s11356-015-4294-0

Schwyn B, Neilands JB (1987) Universal chemical assay for the detection and determination of siderophores. Anal Biochem 160:47-56

Sharma A, Johria BN, Sharma AK, Glick BR (2003) Plant growth-promoting bacterium Pseudomonas sp. strain GRP3 influences iron acquisition in mung bean (Vigna radiata L. Wilzeck). Soil Biol Biochem 35:887-894 https://doi. org/10.1016/S0038-0717(03)00119-6

Siciliano SD, Germida JJ (1999) Taxonomic diversity of bacteria associated with the roots of field-grown transgenic Brassica napus cv. Quest, compared to the non-transgenic B. napus cv. Excel and B. rapa cv. Parkland. FEMS Microbiol Ecol 29(3):263-272. https://doi.org/10.1111/j.1574-6941.1999.tb0061 $7 \times x$

Thierry A, Maillard MB, Lortal S (2002) Detection of aminotransferase activity of Propionibacterium freudenreichii after SDS-PAGE. J Microbiol Methods 51:5762. https://doi.org/10.1016/s0167-7012(02)00060-X

Tirry N, Tahri Joutey N, Sayel H, Kouchou A, Bahafid W, Asri M, El Ghachtouli N (2018) Screening of plant growth promoting traits in heavy metals resistant bacteria: Prospects in phytoremediation. J Gen Engin Biotech 16(2):613-619. https://doi.org/10.1016/j.jgeb.2018.06.004

Vansuyt G, Robin A, Briat JF, Curie C, Lemanceau P (2007) Iron acquisition from Fe-pyoverdine by Arabidopsis thaliana. Mol Plant-Microbe Interact 20:441447. https://doi.org/10.1094/MPMI-20-4-0441

Vincent JM (1947) Distortion of fungal hyphae in the presence of certain inhibitors. Nature 159(4051):850. https://doi.org/10.1038/159850b0

Zaidi A, Khan MS, Saif S, Rizvi A, Ahmed B, Shahid M (2017) Role of nitrogenfixing plant growth-promoting rhizobacteria in sustainable production of vegetables. In: Zaidi A, Khan MS (eds) Microbial strategies for vegetable production. Springer, Netherland, pp 49-59 https://www.researchgate.net/ publication/318180861

Zarafshani K, Ghasemi S, Houshyar E, Ghanbari R, Van Passel S, Azadi H (2017) Canola adoption enhancement in western Iran. J Agric Sci Technol 19:47-58

\section{Publisher's Note}

Springer Nature remains neutral with regard to jurisdictional claims in published maps and institutional affiliations. 